\title{
STATUS AND DECLINE CAUSES OF FISHING ACTIVITIES OF THE BARAL RIVER, NATORE, BANGLADESH
}

\author{
*F. A. Flowra, M. A. Islam, S. N. Jahan, M. A. Samad, M. M. Alam
}

\begin{abstract}
The present investigation is a humble attempt to explore fishing techniques of the River Baral from November 2010 to May 2011. Different fish capture methods, fishing gears and crafts that were usually used in the study area have been provided. Hand fishing, cloth fishing, bait fishing and fishing by dewatering were also observed. Causes of habitat degradation and changes of natural habitat and declination of fishes were also observed. Some problems of the fishing community of the study area were also identified. A few policy recommendations have been given in the concluding chapter which may have some positive implication on the life and living of the fishermen in Bangladesh in general and the Baral basin in particular.
\end{abstract}

Keywords: Gears, Crafts, Spears, Hook and lines, decline causes

\section{INTRODUCTION}

River plays an important role in the life and living of the people of a country specially the fishermen. These are also important in terms of huge fisheries resources and other purposes of navigation, irrigation and domestic uses. A single river possess different name at different places, even a five or six km segment has a different name upstream or downstream. Also a single name is used for different rivers in different locations (Alam and Chowdhury, 2006). Bangladesh has vast inland open water (4024934 ha) which is contributing $35.53 \%$ of total fish capture. Total fish production from inland water area in the year 2009-10 was 2381916 mt., as against $82.15 \%$ of the total catch. In case of marine fisheries, fish catch was $517282 \mathrm{mt}$. in 2009-10, as against $17.85 \%$ of the total catch (DoF, 2011). In the year 2007-2008 and 2008-2009 riverine fisheries contributed $136812 \mathrm{mt}$ and $138160 \mathrm{mt}$ of the total production. In 2009-2010 the total fish production was $138160 \mathrm{mt}$ and annual production rate was 7.32\% (DoF, 2011). People living in village beside the rivers and beels harvest the fish almost round the year without any prior investment except catching devices perhaps more than any other countries. The population of Bangladesh depends on wild fish for food and the generation of income. A large portion rural family are engaged in part time fish capture from the rivers and beels (Hughes et al. 1994). For fishing, different types of crafts, gears and traps are used. Different types of fishing method used from prehistoric times and now fishing methods had been modified. Generally gears are those equipments that are used to catch the fishes. The fishermen selected their fishing gears depending on types of water body, different operation area, depth of water and availability of target species to the caught. In Bangladesh fish and fisheries items of inland water still are caught by using traditional crafts and gears. In respects of gears, Ahmed (1962) described 116 Nets, 26 trap of inland

\footnotetext{
* Associate Professor, Department of Fisheries, University of Rajshahi, Rajshahi-6205, Bangladesh.

E-mail: flowrabd@yahoo.com
} 
fishing including hooks and other devices in general way. The fishing gear, along with the vessel, auxiliary equipment and men, constitutes a "fishing unit". The amount of catch by unit depends upon its efficiency and productivity of the fishing grounds (Naidu, 1939). Most of the fishing gears have to break off operation after certain period of activity for rest and repair work (Ahmed, 1958). So, the present study is taken to identify the existing fish capture techniques, diversified fishing gears with decline causes of fishes of the river Baral.

\section{METHODOLOGY}

\section{Description of the location}

River Baral is a branch of the river Ganga, originated from near the charghat at Rajshahi district and passes after joining with the Atrai- Gumani river through Natore and Pabna district finally mingles with the Huga sagar river after joining with the Koratoya river at the south of Shahjadpur of the Shirajgonj district. The total length, width and depth of Baral river are147 km, $125 \mathrm{~m}$. and $6 \mathrm{~m}$, respectively and drainage area about $230 \mathrm{sq}$. $\mathrm{km}$. Some important places located on the banks of the Baral river are-Charghat, Baraigram, Bagatipara, Gurudashpur, chatmohor and Bera (Baby, 2003). Particularly about $23.8 \mathrm{~km}$ length of the river Baral in located Bagatipara, Natore (Fig. 1). The investigation was conducted on this particular region.
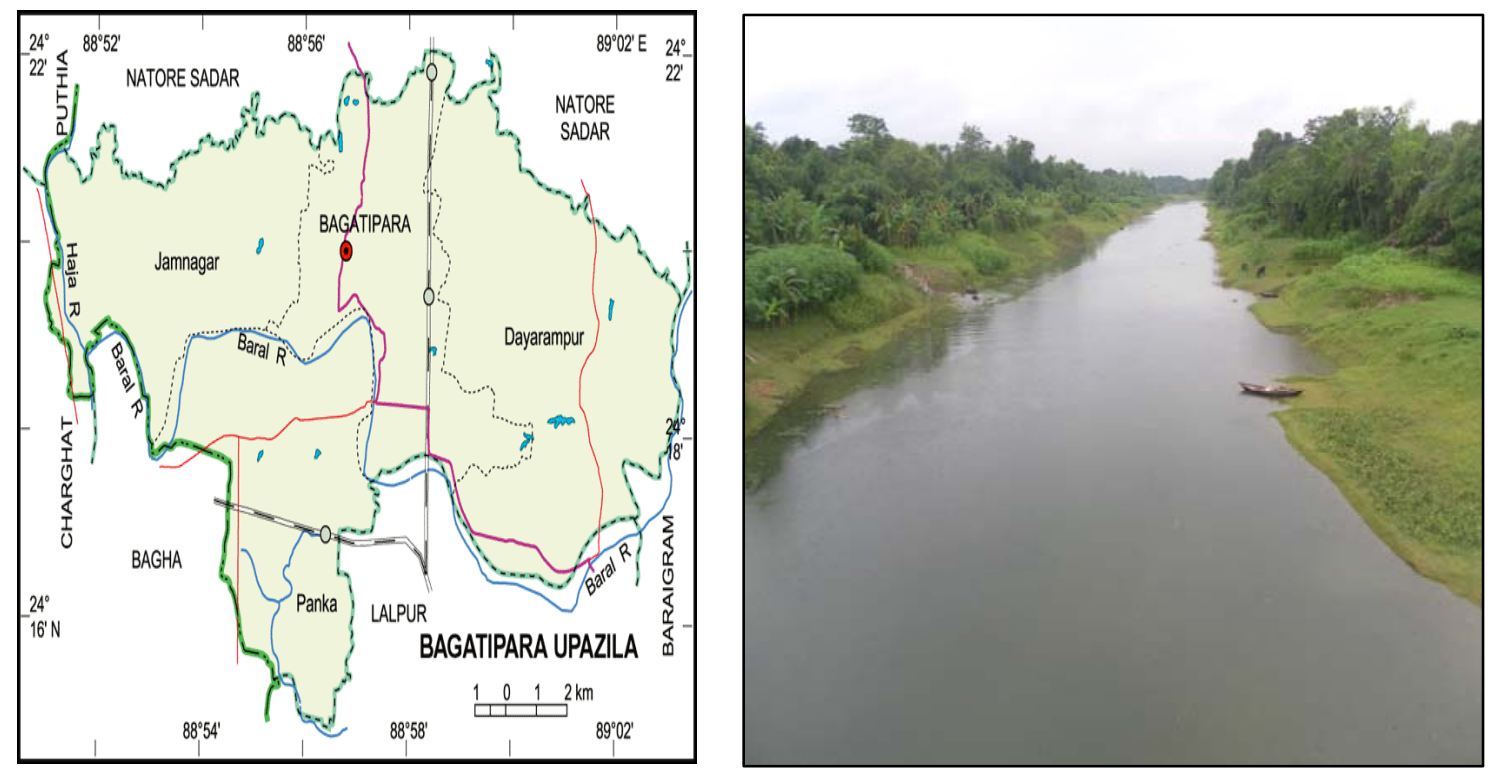

Fig. 1: Showing the study area and partial view of the Baral river

\section{Data collection}

The present study was conducted to assess the fishing activities with impact factors of fishermen of the Baral river in a total period of 7 months from November 2010 to May 2011. 


\section{In-depth interview (IDI)}

A questionnaire was developed in logical sequence of information designed to include both qualitative and quantitative values of findings so that the respondents could answered easily and chronologically. The study was carried out several key issuing interviews with a total of 180 fishermen and 20 womenfolk of the Baral river at fishing sites during fishing time, at household sides during leisure time, and at local fish markets during marketing or purchasing time for individual whereas at Hat, Bazar or Shops for grouped interview. Then findings were cross-checked with the respondents as many as possible.

\section{Eyewitness observation and photograph (EOP)}

Eyewitness observation and photograph facilitated to some issues like fishing and off-fishing activity, fisheries status of the Baral river fishermen those could not be dealt or understood without this method.

\section{RESULT AND DISCUSSION}

\section{Fishing gears:}

A total of 16 types of fishing gears were observed to harvest fish in the study area (Table 1-4). Major categories of gears include nets, traps and hooks. For fishing purpose, a wide variety of nets such as gill nets, seine nets, lift nets, push nets and cast nets were usually used. The fishing traps were Polo, Hancha, kholsun, Chunga, etc. For line fishing chip barshi (hook), wheel barshi, Jiani barshi, Tagi and Daun (longline) were used. All types of gears were broadly classified into four major categories. These groups were nets, traps, hook \& lines and spears.

Chong (1979) studied the fishing gears in Chandpur, Muhuri, Halda and Ichamati project area and recorded 21 different types of gears within the area. According to Dewan and Mazid (1994) the fishing techniques that are currently used amongst the fishermen of Bangladesh have been broadly categorized into netting, angling, trapping, spearing, de-watering and hand fishing. This has been found similar in the present research work.

Jhingran (1989) were reported that the big sized cat fishes (Wallago attu) were generally caught by hook and line. The smaller fishes were bagged by dip nets and cast nets. Beside these many researcher such as Khaled (1985), Rahman et al. (1993), Aosomboon (1994), Dewan and Mazid (1994), Chakraborty et al. (1995), Alam et al. (1997), Das et al. (2003), Alam et al. (2009) worked on fishing activities in beels and rivers. 
Table- 1: Different types of net used for fishing and catch species in the Baral river

\begin{tabular}{|c|c|c|c|c|c|c|}
\hline \multirow{2}{*}{$\begin{array}{c}\text { Types of } \\
\text { gear }\end{array}$} & \multirow{2}{*}{$\begin{array}{c}\text { Name of } \\
\text { gear }\end{array}$} & \multicolumn{3}{|c|}{ Size of net (Approximately) } & \multirow{2}{*}{$\begin{array}{c}\text { No. of } \\
\text { Operatin } \\
\text { g person }\end{array}$} & \multirow[b]{2}{*}{ Catch species (Scientific name) } \\
\hline & & $\begin{array}{l}\text { Length } \\
\text { (m) }\end{array}$ & $\begin{array}{l}\text { Width } \\
\text { (m) }\end{array}$ & $\begin{array}{l}\text { Mesh } \\
(\mathbf{m m})\end{array}$ & & \\
\hline Cast net & $\begin{array}{c}\text { Khepla } \\
\text { jal }\end{array}$ & $4-5$ & $6-9$ & $10-30$ & 1 & $\begin{array}{l}\text { Labeo rohita, Catla catla, Cirrhina mrigala, } \\
\text { Channa punctatus, Channa striatus, Channa } \\
\text { marulius, Colisa faciatus, Mastacembelus } \\
\text { armatus, Puntius ticto, Mystus tengara, } \\
\text { Chanda nama, Gadusia chapra, } \\
\text { Glossogobius giuris, Cirrhina reba, Chela } \\
\text { bacaila, Amblypharyngodon mola, } \\
\text { Xenentodon cancila, Cancer sp, Tetraodon } \\
\text { cutcutia, Macrobrachium rosenbergii, } \\
\text { Ompok pabda, Eutropiichthys vacha, } \\
\text { Clupisoma garua etc. }\end{array}$ \\
\hline Seine net & Ber jal & $100-600$ & $5-6$ & $2-4$ & $4-8$ & $\begin{array}{l}\text { Labeo rohita, Catla catla, Cirrhina mrigala, } \\
\text { Channa punctatus, Channa striatus, Channa } \\
\text { marulius, Puntius ticto, Mystus tengara, } \\
\text { Chandarnama, Gadusia chapra, } \\
\text { Glossogobius giuris, Cirrhina reba, Chela } \\
\text { bacaila, Amblypharyngodon mola, } \\
\text { Xenentodon cancila Tetraodon cutcutia, } \\
\text { Macrobrachium rosenbergii, Channa } \\
\text { punctatus, Channa striatus, Channa } \\
\text { marulius, Mystus aor etc. }\end{array}$ \\
\hline \multirow[b]{2}{*}{ Gill net } & $\begin{array}{c}\text { Current } \\
\text { jal }\end{array}$ & $70-110$ & $5-15$ & $10-15$ & 1 & \multirow{2}{*}{$\begin{array}{l}\text { Puntius ticto , Mystus tengara, Gadusia } \\
\text { chapra, Glossogobius giuris, Cirrhina reba, } \\
\text { Chela bacaila, Xenentodon cancila, Ompok } \\
\text { pabda, Mystus aor, Eutropiichthys vacha } \\
\text { etc. }\end{array}$} \\
\hline & Fash jal & $40-50$ & $0.5-1.0$ & $18-25$ & 1 & \\
\hline \multirow[b]{2}{*}{ Lift net } & Khara jal & $10-14$ & $8-9$ & $16-32$ & 1 & \multirow{2}{*}{$\begin{array}{l}\text { Colisa faciatus, Gadusia chapra, Puntius } \\
\text { ticto, Mystus tengara, Ailia coila, Chanda } \\
\text { nama, Mastacembelus pancalus, Ompok } \\
\text { pabda Anabas testudineus, Channa } \\
\text { punctatus, Channa striatus, Ompok pabda, } \\
\text { etc. }\end{array}$} \\
\hline & $\begin{array}{c}\text { Dharmo } \\
\text { jal }\end{array}$ & $2-3$ & $2-3$ & $7-12$ & 1 & \\
\hline Push net & Thela jal & $3-13$ & $1-2$ & $4-16$ & 1 & $\begin{array}{l}\text { Puntius ticto, Chanda nama, Anabas } \\
\text { testudineus, Amblypharyngodon mola, } \\
\text { Mystus tengara, Rasbora daniconius, } \\
\text { Mastacembelus armatus, Mastacembelus } \\
\text { pancalus, Macrobrachium rosenbergii etc. }\end{array}$ \\
\hline
\end{tabular}


Table-2: Different types of traps used for fishing at catch species in the Baral river.

\begin{tabular}{|c|c|c|c|c|c|}
\hline \multirow[b]{2}{*}{$\begin{array}{c}\text { Name of } \\
\text { traps }\end{array}$} & \multicolumn{3}{|c|}{ Size of trap (Approximately) } & \multirow[b]{2}{*}{ Made with } & \multirow{2}{*}{$\begin{array}{l}\text { Catch species } \\
\text { Scientific name }\end{array}$} \\
\hline & Height & Length & $\begin{array}{l}\text { Width/ } \\
\text { Dia. }\end{array}$ & & \\
\hline Kholsun & $1.5-2 \mathrm{ft}$ & $2.5-5 \mathrm{ft}$ & $0.33-0.5 \mathrm{ft}$ & $\begin{array}{l}\text { Bamboo } \\
\text { stick }\end{array}$ & $\begin{array}{l}\text { Puntius ticto, Chanda nama, } \\
\text { Amblypharyngodon mola, Mystus } \\
\text { tengara, Rasbora daniconius, } \\
\text { Mastacembelus pancalus, etc. }\end{array}$ \\
\hline Polo & $\begin{array}{c}0.7-1.0 \\
\mathrm{~m}\end{array}$ & - & $0.5-0.6 \mathrm{mt}$ & $\begin{array}{c}\text { Bamboo } \\
\text { split }\end{array}$ & $\begin{array}{l}\text { Channa punctatus, Channa striatus, } \\
\text { Channa marulius, Mastacembelus } \\
\text { armatus, Mastacembelus pancalus, } \\
\text { Anabas testudineus etc. }\end{array}$ \\
\hline Chunga & - & $2-3 \mathrm{ft}$ & - & Bamboo & $\begin{array}{l}\text { Mastacembelus armatus, Mastacembelus } \\
\text { pancalus, Heteropneustes fossilis, } \\
\text { Clarias batrachus etc. }\end{array}$ \\
\hline Hancha & $10 \mathrm{ft}$ & $2-4 \mathrm{ft}$ & $2-2.5 \mathrm{ft}$ & $\begin{array}{c}\text { Bamboo } \\
\text { split }\end{array}$ & $\begin{array}{l}\text { Rasbora daniconius, Colisa faciatus, } \\
\text { Mastacembelus } \\
\text { Macrobrachium lamarrei etc. }\end{array}$ \\
\hline
\end{tabular}

Table-3: Different types of hooks and lines used for fishing and catch species in the Baral river

\begin{tabular}{|c|c|c|c|c|c|}
\hline $\begin{array}{l}\text { Types } \\
\text { of gear }\end{array}$ & $\begin{array}{c}\text { Name of } \\
\text { gear }\end{array}$ & $\begin{array}{l}\text { No. of } \\
\text { hooks }\end{array}$ & $\begin{array}{l}\text { Person } \\
\text { needed }\end{array}$ & Boat needed & Catch species \\
\hline \multirow[t]{4}{*}{$\begin{array}{c}\text { Hook } \\
\text { and line }\end{array}$} & Chip barshi & 1 & 1 & $\begin{array}{l}\text { no boat } \\
\text { needed }\end{array}$ & $\begin{array}{l}\text { Channa punctatus, Mystus } \\
\text { tengara, } \\
\text { fossilis, Meteropneustes } \\
\text { Puntius ticto, Chela bacaila, } \\
\text { Labeo rohita, Cirrhina mrigala, } \\
\text { Labeo calbasu etc. }\end{array}$ \\
\hline & $\begin{array}{l}\text { Wheel } \\
\text { barshi }\end{array}$ & $1-4$ & 1 & $\begin{array}{l}\text { no boat } \\
\text { needed }\end{array}$ & $\begin{array}{l}\text { Heteropneustes fossilis, Clarias } \\
\text { batrachus, Channa punctatus, } \\
\text { Channa striatus, Labeo rohita } \\
\text { Labeo calbasu Cirrhina } \\
\text { mrigala Catla catla, Cirrhina } \\
\text { reba etc. }\end{array}$ \\
\hline & Jiani barshi & $1-2$ & $1-2$ & $\begin{array}{l}\text { no boat } \\
\text { needed }\end{array}$ & $\begin{array}{l}\text { Wallago attu, Channa } \\
\text { marulius, Channa striatus, } \\
\text { Notopterus } \\
\text { etc. }\end{array}$ \\
\hline & Tagi & $3-7$ & 1 & $\begin{array}{l}\text { no boat } \\
\text { needed }\end{array}$ & $\begin{array}{l}\text { Heteropneustes fossilis, Clarias } \\
\text { batrachus, Channa punctatus, } \\
\text { Channa striatus, Anabas } \\
\text { testudineus, Channa marulius, } \\
\text { Mystus aor, carp etc. }\end{array}$ \\
\hline
\end{tabular}




\begin{tabular}{|l|l|l|l|l|}
\hline & & & & $\begin{array}{l}\text { Ailiichthys punctata, } \\
\text { Eutropiichthys vacha, ,Mystus } \\
\text { aor, Mystus bleekeri, Rita rita, } \\
\text { Lotopterus notopterus, Stipinna } \\
\text { phasa, Wallago attu, Mystus } \\
\text { aor etc. }\end{array}$ \\
\hline
\end{tabular}

Table-4: Different types of Spears used for fishing and catch species in the Baral river

\begin{tabular}{|c|c|c|c|l|}
\hline \multirow{2}{*}{$\begin{array}{c}\text { Types } \\
\text { of gear }\end{array}$} & $\begin{array}{c}\text { Name of } \\
\text { gear }\end{array}$ & $\begin{array}{c}\text { Length } \\
\text { of } \\
\text { handle } \\
\text { (m) }\end{array}$ & $\begin{array}{c}\text { Parson and boat } \\
\text { needed }\end{array}$ & \multicolumn{1}{|c|}{ Catch species } \\
\hline \multirow{2}{*}{ Spear } & Konch & $2-3$ & 1 \& no & $\begin{array}{l}\text { Wallago attu, Channa striatus, Channa } \\
\text { marulius etc. }\end{array}$ \\
\cline { 2 - 5 } & Teta & $2-3$ & 1 \& no & $\begin{array}{l}\text { Wallago attu, Channa striatus, Channa } \\
\text { marulius etc. }\end{array}$ \\
\cline { 2 - 5 } & Angta & $2-4$ & 1 \& no & $\begin{array}{l}\text { Mastacembelus armatus, Mastacembelus } \\
\text { pancalus, Heteropneustes fossilis etc. }\end{array}$ \\
\hline
\end{tabular}

\section{Fishing crafts:}

Different types of fishing crafts like kosa boat, vedi boat, dingi boat, bhoat boat, and rafts were dominantly used for fish capture (Table 5). Commonly used crafts were of various types, sizes and designs. Ahmed (1954) and Hussain (1977) described the utilization of traditional crafts. Different types of crafts are also essential to assure a good and effective fishing. The fresh water fishing craft and gears are of traditional types, using from long times without any modifications. Same observation or results are found in the study area. Most of the fishing gears have to break off operations after a certain period of activity, for rest and repair (Khanna, 1989).

Table-5: Different types of Crafts used for fishing in the studied area

\begin{tabular}{|l|c|c|l|c|}
\hline \multirow{2}{*}{ Craft name } & \multicolumn{2}{|c|}{$\begin{array}{c}\text { Measurment of } \\
\text { the craft }\end{array}$} & \multicolumn{1}{|c|}{ Gear used in craft } & Man power needed \\
\cline { 2 - 4 } & $\begin{array}{c}\text { Length } \\
(\mathbf{m})\end{array}$ & $\begin{array}{c}\text { Wide } \\
(\mathbf{m})\end{array}$ & & \\
\hline Kosa boat & $3-5$ & $1-2$ & Khepla jal, ber jal etc. & $1-6$ \\
\hline Dinghy boat & $4-10$ & $1-2$ & Ber jal, fash jal, veshal jal & $1-10$ \\
\hline Bhoat boat & $4-7$ & $1.5-2$ & $\begin{array}{l}\text { Khepla jal, current jal, barshi, fash } \\
\text { jal }\end{array}$ & $2-6$ \\
\hline Raft & $2-3$ & $1-1.5$ & Khepla jal, barshi, fash jal & $1-2$ \\
\hline
\end{tabular}




\section{Other Types of Fishing:}

\section{Fishing by hand}

Fishermen capture fishes by hand during the coming flood when the bank side of the river Baral was inundated with water. Fish were also caught by hands from a depth of 3 to 8 feet depth.

\section{Cloth fishing}

A large piece of cloth is used to collect small fishes, larvae etc. Two men hold the corner of the cloth, dip in water and fishes are collected. Usually children and women catch fish with the help of a "gamchha or shari".

\section{Bait fishing}

During the study baits used in capture fishes in River Baral. The baits were of animal origin, plant origin and sometimes chemicals were used with the ground baits, The anglers and fishermen prefer different types of bait for different catches. According to uses bait can be classified into various types. Rahman et al. (1983) done their research work and described on baits and bait fishing of the Padma river near Rajshahi.

\section{Fishing by de-watering}

De-watering by various traditional methods like plate dish or wooden container from the close water area of the bank of the rivers during post monsoon period. Sometimes the shallow water area was completely isolated by creating provisional dam with mud. Then fish and other fisheries items were caught by hands or using hand net.

\section{Factors affecting fishing activities:}

In the study area few causes were identified for this declination of fishing activities from the river Baral. These included the followings-

\section{Degradation of fishes}

The fish species that could be found years back has become rare in the study area. Many species were recorded as endangered and threatened which were available in early decades. The daily newspaper prothom alo (2012) reported that already 16 species are extincted.

\section{Change of natural habitats}

Due to natural causes like shrinkage of genetic base and manmade causes like water pollution through industrial wastage, sewerage wastage, agricultural wastage, destroyed the spawning, nursing and grazing grounds of fish species of the river Baral. 


\section{Construction of the Farrakka Barrage and water diversion}

Construction of the Farrakka Barrage at the upstream caused major detrimental catastrophe for the ecosystem of the river Baral. The migratory route of Hilsa has largely been affected for this reason.

\section{Excessive use of river water for irrigation purpose}

Excessive use of river water and reclamation of land for agricultural purpose (irrigation) resulted shrinkage of spawning and feeding grounds for fish species.

\section{Siltation due to less water flow}

Siltation at the upstream of the river was a serious threat that caused reduction of water flow and as a result spawning and nursing grounds of many fishes have been drastically affected in recent years.

\section{Construction of sluice gate}

There were two sluice gates on the river Baral such as: Charghat and Atghoria sluice gate. These two constructions adversely affect on fisheries diversity and livelihood of the adjacent fishermen. The daily newspaper Prothom Alo (2012) reported that five hundreds fishermen are already are unemployed.

Due to the combination of both natural and manmade factors fisheries resources from the river Baral were depleting day by day. Huge fishing activities that could be found years back is now alarming. With the increase of use of river water for irrigation, domestic use of river water, siltation, habitat degradation and pollution, the capture fishery of the river Baral was facing a real danger now these days. Aguero (1989) described that over fishing, high population, sedimentation, flood and tidal control projects, excessive removal of surface water for irrigation, large scale reclamation of rivers, haors, beels and other depression areas for crop production caused severe problems for inland fisheries. Karim (1978) stated that in the past time inland open water was the principal source of production and about $90 \%$ fish was captured from the inland open water. To observe the fishing community of the study area it had been seen that, the stocking or richness of fish and fisheries resources of the river Baral as well as of the open waters of our country has been greatly affected. Some species were very rare at this moment those were available in few years ago eg. Nandus nandus, Labeo gonia, Tor tor, Channa marulius, Pangasius pangasius etc.

\section{RECOMMENDATIONS}

\section{Recommendations on fishing activity}

Cage culture, pen culture, and community based fisheries management should be adopted in this Baral during off-season when the river water dropped. 


\section{Recommendations on fishermen's livelihoods}

- DoF, NGOs and other developing agencies and fisheries expert should provide appropriate knowledge or training on fishing or net weaving.

- A new micro credit service system should be installed for the Baral river fishermen during offseason to perform off-fishing and non-fishing activity.

- Local, regional, national and international NGOs should provide technical knowledge, credit support and alternative income sources available to the poor fishermen as well as womenfolk.

\section{CONCLUSION}

At present environmental degradation (erosion, siltation, Chars formation, cropland damage) where its fishermen livelihood mostly depended upon only on fishing activity performed here. If these are continue such a way, the fishermen do not able to perform a good and sustainable life portfolios in the future and they will thrown very back where from they could not improve again. That is why; some recommendations are made to mitigate these affects to improve their livelihood status potentiality. The government as well as non-government initiatives also should come forward to consider these pessimistic impacts and develop such techniques or alternatives that help at least the poor fishermen to hold present profession of fishing in the Baral river.

\section{REFERENCES}

Aguero, M. 1989. Inland Fisheries in Bangladesh: Management Options and National Interventions, Proceedings of the ICLARM/DOF/BCAS Workshop on Experiments in New Approaches to the Improved Management of Open Water Fisheries in Bangladesh, Dhaka, Bangladesh,1-13 pp.

Ahmed, N. 1954. Fishing craft of East Pakistan. Directorate of Fisheries. East Pakistan Govt. Tech. 20.

Ahmed, N. 1958. Socio-economic of fishing Industry. Directorate of Fisheries. East Pakistan Govt. Press, Dacca.

Ahmed, N. 1962. Fishing gear of East Pakistan. Directorate of Fisheries, East Pakistan Govt. Press, Dacca, 1-35.

Alam, M. S. and Chowdhury, M. H. 2006. Banglapedia: National Encyclopedia of Bangladesh. Bengali and English Combined CD Edition. Copyright by Asiatic Society of Bangladesh.

Alam, S. S., Ali, M. Y. and Tsai, C. F. 1997. Fishing Gear of Floodplain Fisheries in Bangladesh: A Case Study of Chanda, BSKB and Halti Beels. Openwater Fisheries of Bangladesh, Editors: Chu-fa Tsai and M. Yousouf Ali, Bangladesh Centre for Advanced Studies, The University Press Limited, Dhaka, Bangladesh, 137-152.

Alam, M. S., Flowra, F. A., Salam, M. A., Kabir, A. K. M. A. and Ali, H. 2009. Fishing gears, fish marketing and livelihood status of the poor fishermen around the Basantapur beel at Lalpur Upazila. Journal of Agroforestry and Environment, 3(1): 17-20.

Aosomboon, P. 1994. Small-scale Fishing Gear Used in the Artificial Reef Areas, Ranong Province, Thailand. In: The Effect of Artificial Reef Installation on the Bio-socioeconomics of Smallscale Fisheries in Ranong Province, Thailand. Bay of Bengal programme for Fisheries Development, Madras, India. Small-scale Fisherfolk Communities in the Bay of Bengal. 5365 pp. 
Baby, S. N. 2003. Baral River. Banglapedia: National Encyclopedia of Bangladesh. English Edition. Asiatic Society of Bangladesh. p.61.

Chakraborty, R. D., Roy, P. and Singh, S. B. N. 1995. A Quantitative Study of the Plankton and the Phisico-chemical condition of the Jamuna at Allahabad. Indian J. Fish., 6(1): 186-203.

Chong, K. C. 1979. An economic appraisal of the fisheries in the Chandpur, Muhuri, Halda and Ichamatic Project areas. Irrigation Fishery Development Project. Working Document No. 13, Directorate of Fisheries, Bangladesh and Snell Environmental Group, Inc., U.S.A.

Das, T., Das, K., Dutta, N. and Gupta, A. 2003. Status of capture fishery in river Barak, Assam, India. The Second International Symposium on the management of large rivers for fisheries. 11-14 February, 2003, Phnom Penh, Combodia.

Dewan, S. and Mazid, M. A. 1994. Productivity, Exploitation and Fishing Technology of Inland water Fisheries, Bangladesh. A report prepared for the project "Assistance to fisheries Research Institute" (BGD/89/OV) FRI/FAO/UNDP.

DoF, 2011. Matsha Pakkha Sankalan-2011. Department of Fisheries. The Government of Peoples Republic of Bangladesh. 117.121 pp.

Hughes, R., Adnan, S. and Dalal-Clayton, B. 1994. Floodplains or flood plans? International Institute for Environment and Development and Research and Advisory services, London.

Hussain, M. 1977. Design of two standard steel body fishing crafts for all seasons operation in the Bay of Bengal, National marine Fisheries seminar. Edited by A. L. Bhuiyan and A. K. Chowdhury.

Jhingran, V. G. 1989. Fish and fisheries of India. Hindustan Publishing Corporation (India) Delhi. 666 p.

Karim, A. 1978. Socio-economic survey of village Sahapur: a Project work submitted in the Department of Sociology, Rajshahi University. 48 p.

Khaled, M. 1985. A Manual Survey on Fishing Gear and Catch Assessment in Bangladesh. Bangladesh J. Aquaculture. Vol. 6-7 (1). P. 31-34.

Khanna, S. S. 1989. An introduction to fishes. Published by central book dept. Allahabad. $2^{\text {nd }}$ ed. 486 p.

Naidu, M.R. 1939. Report on survey of the fisheries of Bengal. Calcutta Govt. Printer.

Prothom Alo. 2012. Staff Reporter. A report on Mritopri Baral Nod ke Bachanor Udjogh (in Bengali). The daily newspaper. Date:15.05.2012. Uttor-4.

Rahman, S., Chakraborty, B., Razzak, A., Paul, S. K. and Tsai, C. 1993. The Study on Fishing Gear Selectivity. Preliminary Progress Report, May 1993. Fisheries Research Institute, Third Fisheries Project, Shantahar, Bogra. 1-27 pp.

Rahman, Y., Afroze, S. and Hossain M. A. 1983. Bait and bait fishing of the river Padma. Raj. Fish. Bull., Special Issue on the Padma river, Vol. 1, No. 2, 38-43. 